\title{
Validation of High-Performance Liquid Chromatography for Determination of Bromelain in Pineapple (Ananas comosus (L) Merr) Water
}

\author{
Novi Yantih ${ }^{1, *}$, Alfadella Methananda ${ }^{1}$, Yahdiana Harahap ${ }^{2}$, Wahono Sumaryono ${ }^{1}$, Lestari Rahayu ${ }^{1}$
}

Novi Yantih ${ }^{1, *}$, Alfadella

Methananda ${ }^{\prime}$, Yahdiana

Harahap ${ }^{2}$, Wahono

Sumaryono ${ }^{1}$, Lestari Rahayu ${ }^{1}$

${ }^{1}$ Faculty of Pharmacy, Universitas Pancasila, South Jakarta, Jakarta, INDONESIA.

${ }^{2}$ Faculty of Pharmacy, Universitas

Indonesia, Depok, West Java, INDONESIA.

\section{Correspondence}

\section{Novi Yantih}

Faculty of Pharmacy, Universitas Pancasila, South Jakarta, Jakarta, INDONESIA

E-mail: novi_yantih@yahoo.com

History

- Submission Date: 02-02-2019;

- Review completed: 18-05-2019;

- Accepted Date: 25-07-2019.

DOI : 10.5530/pj.2019.11.144

Article Available online http://www.phcogj.com/v11/i5

\section{Copyright}

(c) 2019 Phcogj.Com. This is an open access article distributed under the terms of the Creative Commons Attribution 4.0 International license.

\begin{abstract}
Objective: The aim of the present study was to validate HPLC method for analysis bromelain levels in pineapple water and application that method to determine the storage time of pineapple water. Methods: The reversed phase of HPLC method was tested and optimized before it is validated. The composition and the flow rate of the mobile phase is the optimized parameter. The analytical parameters validated were detection limits, linearity, accuracy and precision. Pineapple water was stored for $8 \mathrm{~h}$ at $10^{\circ} \mathrm{C}$ and bromelain was determined using the validated HPLC method. Result: The optimum mobile phase composition was methanolwater (70:30) with a flow rate of $1 \mathrm{ml} / \mathrm{min}$. The detector concentration-response was linear with coefficient of determination of 0.993 . The accuracy of HPLC method at a recovery of 1 and $2 \%$ bromelain was $106.37 \pm 1.94 \%$ and $98.12 \pm 1.29 \%(n=5)$, respectively. The precision, expressed as the coefficients of variation (CV), at 1 and $2 \%$ bromelain were 1.83 and $1.32 \%$ $(n=5)$, respectively. Bromelain level at zero time was $81.53 \%$. After storage for $8 \mathrm{~h}$ at $10^{\circ} \mathrm{C}$, bromelain levels in pineapple juice appeared to decrease not statistically significant $(p>0.05)$, with to mean value of $78.46 \pm 2.88 \%$. Conclusion: The HPLC method developed was valid to analyze accurately concentrations of bromelain in pineapple water and it can be used to study the shelf life of pineapple water based on bromelain content. The bromelain content in pineapple juice was not statistically significantly different after $8 \mathrm{~h}$ storage at $10^{\circ} \mathrm{C}$.

Key words: Bromelain, HPLC, Pineapple water, Storage.
\end{abstract}

\section{INTRODUCTION}

Pineapple fruit (Ananas comosus (L). Merr) contains nutrients that are beneficial to health. Nutritional content in pineapple fruits include water, protein, fat, carbohydrates, calcium, phosphorus, iron, vitamin $A$, vitamin $B$ and vitamin $C .{ }^{1}$ In addition, pineapple fruit also contains protease enzymes including ananine, comosain and bromelain. Bromelain levels concern the highest protease enzyme in pineapple. Bromelain can be found in all tissues of pineapple plants, including the stem, fruit and leaves.

Pineapple fruit has phamacological benefits, because it contains high bromelain concentrations. ${ }^{2}$ Bromelain possesses multiple therapeutic activities. In vitro and in vivo studies demonstrate that bromelain exhibits various fibrinolytic, antiedematous, antithrombotic and antiinflammatory activities. Bromelain is considerably absorbable in the body without losing its proteolytic activity and without producing any major side effects. Bromelain accounts for many therapeutic benefits like the treatment of angina pectoris, bronchitis, sinusitis, surgical trauma and thrombophlebitis, debridement of wounds and enhanced absorption of drugs, particularly antibiotics. It also relieves osteoarthritis, diarrhea and various cardiovascular disorders. Bromelain also possesses some anticancerous activities and promotes apoptotic cell death. ${ }^{3-5}$ Bromelain proved to be effective at controlling postoperative pain at 48 $72 \mathrm{~h}$ after surgery, but did not achieve a significant effect in comparison to the control group with regard to oedema or trismus. ${ }^{6}$

Pineapple fruit consumption is one way to get nutrients in pineapple. Pineapple fruit water is consumed directly after the manufacturing process or after being stored for a while after the manufacturing process. Shelf life is the time within which a product remains stable. This can be established from chemical properties during storage. Base on vitamin C level, shelf life studies of pineapple juice have been reported. ${ }^{7,8}$ Bromelain can be used as an indicator of the quality of pineapple fruit, because bromelain is the largest component of the protease enzyme in pineapple. $^{2}$

In general, enzymes acting as biocatalysts have an unstable nature in their environment. ${ }^{9}$ Enzyme levels and activities can be affected by temperature, $\mathrm{pH}$ and physical modification during storage. Bromelain is sensitive to high temperatures, acidity and organic solvents. ${ }^{10-12}$ This instability will result in decreased enzymatic activity and limit its pharmacological effects. ${ }^{2}$ Consequently, a study is needed to determine the bromelain content during storage of pineapple fruit water. In order to determine the bromelain contents, a validated analytical method is needed.

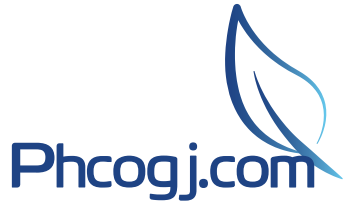

Cite this article: Yantih N, Methananda A, Harahap Y, Sumaryono W, Rahayu L. Validation of High-Performance Liquid Chromatography for Determination of Bromelain in Pineapple (Ananas comosus (L) Merr) Water. Pharmacog J. 2019;11(5):901-6. 
Several chromatographic techniques, such as ion exchange chromatography, high-speed counter-current chromatography, affinity chromatography, gel filtration chromatography and capillary electrochromatography have been employed for the purification of bromelain., ${ }^{3,13}$ Gradient eluation of high performance liquid chromatography (HPLC) has been reported to determine of bromelain in crude bromelain ${ }^{14}$ and stem bromelain. ${ }^{5}$ Bromelain has been quantified by visible spectrophotometry in tablets ${ }^{15}$ and by HPLC in gel formulation. ${ }^{16}$ Determination of bromelain content in pineapple water by isocratic HPLC method using spesific column and UV detection has been reported..$^{17}$ Therefore, this study aims to develop and validate a novel isocratic HPLC method with photodiode array detector for the analysis of bromelain contents in pineapple fruit water. The validated method is also used to determine the effect of storage of pineapple fruit water on levels of bromelain.

\section{MATERIALS AND METHODS}

\section{Materials}

Pineapple (Ananas comosus), Smooth Cayenne type, was obtained from Subang, West Java, Indonesia. The fruit was determined at the "Herbarium Bogoriense" Botanical Field of the Biological Research Central, Indonesian Institute of Sciences, Cibinong-Bogor, Indonesia. Bromelain (Sigma Aldrich, Missouri, United State of America) was used as Reference standard. Methanol (Merck, Darmstadt, Germany) was pro HPLC grade.

Equipments: The main equipment components used in this research were a Knauer Smartline S2600 (Knauer, Berlin, Germany), a juicer (Kuche, Jakarta, Indonesia) and Eppendorf tubes (Eppendorf, Hamburg, Germany).

\section{Methods}

Preparation of pineapple water: Pineapple fruit was cut into small pieces and then mixed with a juicer, then put in a glass container and covered with plastic wrap and stored in a refrigerator at $10^{\circ} \mathrm{C}$.

Optimization of mobile phase of HPLC system: Selection of the mobile phase was carried out to obtain the mobile phase composition which can provide effective and efficient results in HPLC analysis. Chromatograph conditions were supported with C18 (150 $\mathrm{mm} \times 4,6$ $\mathrm{mm})$ as stationary phase, methanol-air as mobile phase with flow rate of $0.8,1.0$ and $1.2 \mathrm{~mL} / \mathrm{min}$ and photodiode array (PDA) as a detector at $230 \mathrm{~nm}$. The system suitability test was done before analysis.

Calibration curve: Calibration curves were made to determine the concentration of analytes in the sample. The series solutions of bromelain with concentrations of $1,2,4,6,8$ and $10 \%$ were prepared in methanol. A total of $20 \mu$ of solution was injected into the chromatograph at each concentration. The curve is made from the relationship between analyte and concentration.

\section{Validation of HPLC methods}

Linearity test: A total of 8 sample concentrations were made to test linearity. Pineapple juice samples as much as $0.1 ; 0.2 ; 0.4 ; 0.6 ; 0.8$; $1.0 ; 1.2$; and $1.4 \mathrm{~mL}$ were inserted into each measuring flask, then added with methanol to $5 \mathrm{ml}$. A total of $20 \mu$ of solution from each concentration was injected into the chromatograph. The correlation coefficient ( $r$ ) of the curve is made from the relationship between analyte and concentration.

Accuracy test: Determination of the accuracy of the method was using the addition method of $1 \%$ and $2 \%$. A total of $20 \mu \mathrm{l}$ of solution was injected into the chromatograph as many as 5 times of each concentration. Accuracy can be determined by calculating of recovery. precision test: Determination of the precision of the method was using the addition method of $1 \%$ and $2 \%$. A total of $20 \mu \mathrm{l}$ of solution was injected into the chromatograph as many as 5 times of each concentration. Precision was calculated as the coefficient variance of each concentration.

Determination of bromelain in pineapple fruit water: Pineapple fruit water is stored for several times, namely $0,1,2,4$ and $8 \mathrm{~h}$. Bromelain levels were analyzed at each storage time. Sample was filtering using filter paper. Filtrate was pipetted as much as $0.4 \mathrm{~mL}$ and put into a 5 $\mathrm{mL}$ flask and added with methanol to $5 \mathrm{~mL}$, then homogenized. The solution was filtered with a $0.2 \mu \mathrm{m}$ membrane filter and sonicated for $15 \mathrm{~min}$ before injected to chromatograph.

\section{RESULT AND DISCUSSION}

\section{Optimization of mobile phase of HPLC system}

In the method optimization, a composition of methanol-water ratio (70:30) with a flow rate of $1 \mathrm{~mL} / \mathrm{min}$ was perform as a mobile phase. The chromatograms can be seen in Figure 1 and Table 1. From Figure 1, the peak of bromelain was appears in a 2-min time retention time. Peak area of the analyte was greater at a flow rate of $1 \mathrm{~mL} / \mathrm{min}$ than 0.8 and $1.2 \mathrm{~mL} / \mathrm{min}$. This showed that the sensitivity of the method increased at a flow rate of $1 \mathrm{~mL} / \mathrm{min}$.

This proposed method is more efficient than reported method, ${ }^{5,16}$ since the retention time of bromelain appeared at $2 \mathrm{~min}$.

\section{System suitability test}

In the system suitability test, the standard solution of bromelain was at a concentration of $6 \%$. The test results showed the CV value of the area and retention time $(n=5)$ of 1.07 and $1.49 \%$, respectively. This value indicates a system suitability met the requirements with $\mathrm{KV}$ of $\leq 2 \%$ (18).

\section{Linearity test}

The linearity test is used to describe the correlation of response and the concentrations. Linearity is showed by coefficient determination $\left(\mathrm{R}^{2}\right)$ that closes to 1 . The linearity of method was met requirement ${ }^{18}$ with $\mathrm{R}^{2}$ of 0.993 (Figure 2). Thus, it can be concluded that the method produces a linear response to the concentrations of bromelain.

\section{Accuracy and precision test}

The accuracy and precision tests are carried out by the standard addition method which is to add a reference standard into the sample. This method is chosen because it cannot create a sample matrix without analytes. Reference standard added to the sample is 1 and $2 \%$ for efficient use of raw materials. The accuracy of an analytical method describes the closeness of the determined value obtained by the method to the nominal concentration of the analyte (expressed in percentage). The result showed that the recoveries at the addition of 1 and $2 \%$ bromelain were $106.37 \pm 1.94 \%$ and $98.12 \pm 1.29 \%(n=5)$, respectively. The precision of the analytical method describes the closeness of repeated individual measures of analyte. Precision is expressed as the coefficient of variation $(\mathrm{CV})$. The result showed that the $\mathrm{CV}$ values at the addition of 1 and $2 \%$ bromelain were 1.83 and $1.32 \%(n=5)$. This proposed method met the accuracy and precision according to $\mathrm{ICH} .{ }^{18}$

\section{Analysis of bromelain in pineapple fruit water at various storage time}

Bromelain level at zero time was $81.53 \%$. Bromelain levels in pineapple water showed decrease after storage for $8 \mathrm{~h}$ at $10^{\circ} \mathrm{C}$ (Figure 3). Bromelain levels in pineapple juice appeared to decrease not statistically significant $(\mathrm{p}>0.05)$ after storage for $8 \mathrm{~h}$ at $10^{\circ} \mathrm{C}$, with to mean value of 78.46 $\pm 2.88 \%$. The relative declines in the levels of bromelain were 91.17 99.14\% from 1 to $8 \mathrm{~h}$ at $10^{\circ} \mathrm{C}$ (Figure 4 ). 

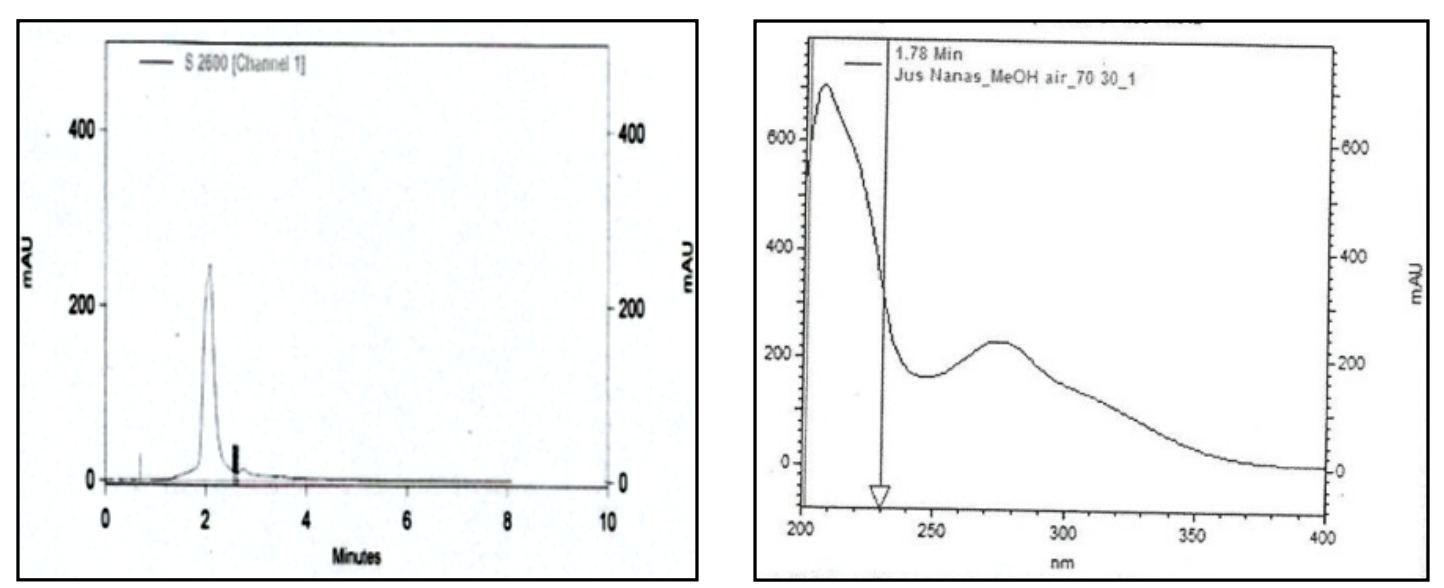

(a)
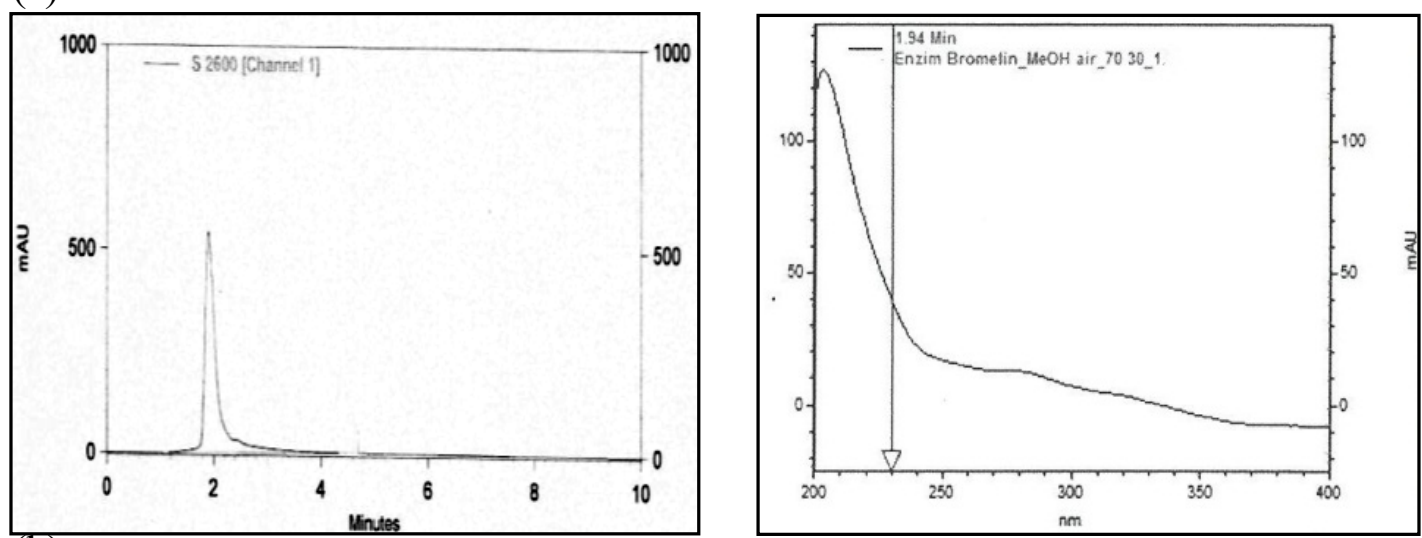

(b)

Figure 1: Chromatogram (left) and UV-spectra (right) of bromelain in pineapple water (a) and reference (b).

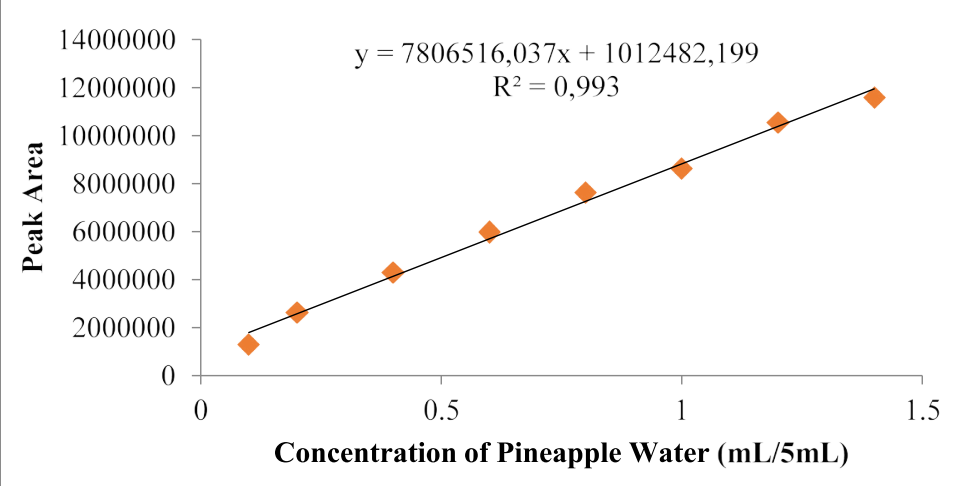

Figure 2: Calibration curve of bromelain in pineapple water as a matrix.

Table 1: The retention time and peak area of bromelain at various flow rate of mobile phase.

\begin{tabular}{ccccc}
\hline \multirow{2}{*}{$\begin{array}{c}\text { Flow Rate } \\
(\mathrm{mL} / \mathrm{min})\end{array}$} & \multicolumn{2}{c}{ Retention Time of Analyt (minutes) } & \multicolumn{2}{c}{ Peak Area } \\
\cline { 2 - 5 } & Reference & $\begin{array}{c}\text { Pineapple } \\
\text { Water }\end{array}$ & Reference & $\begin{array}{c}\text { Pineapple } \\
\text { Water }\end{array}$ \\
\hline 0.8 & 2.133 & 2.300 & 811943 & 4900948 \\
1.0 & 2.167 & 2.367 & 929218 & 4921142 \\
1.2 & 1.950 & 1.800 & 851046 & 3571425 \\
\hline
\end{tabular}




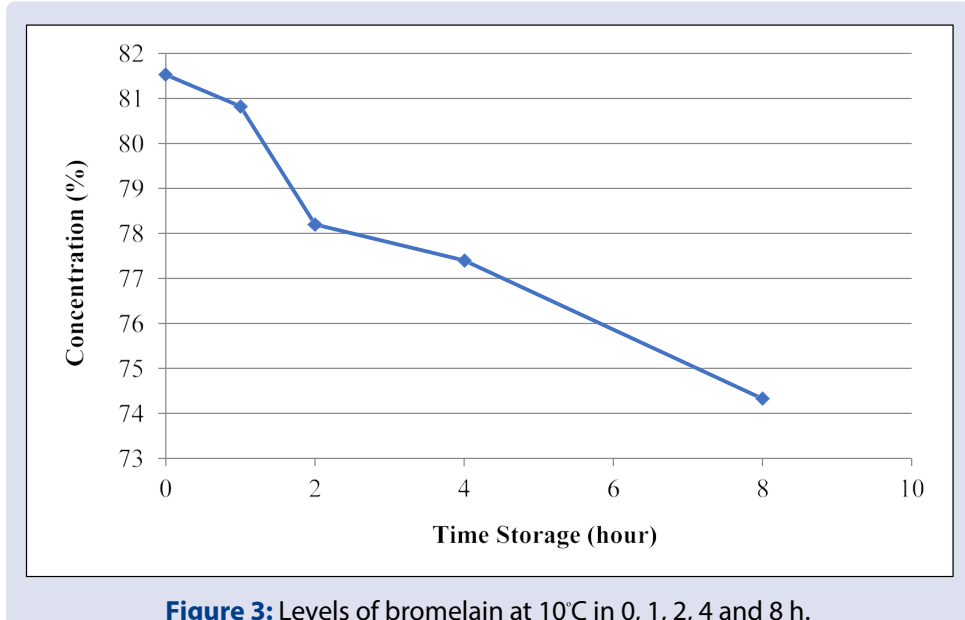

Figure 3: Levels of bromelain at $10^{\circ} \mathrm{C}$ in $0,1,2,4$ and $8 \mathrm{~h}$.

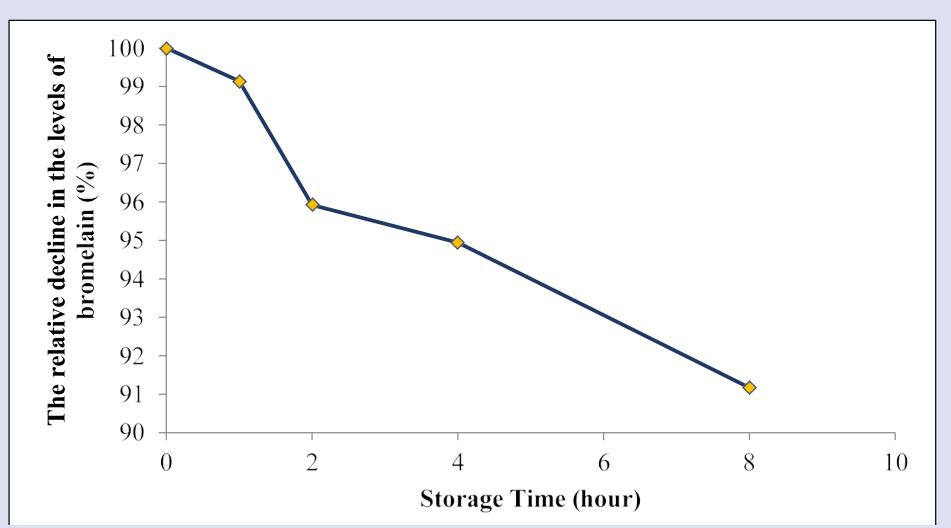

Figure 4: The relative declines in the levels of bromelain depend on the storage time.

\section{CONCLUSION}

The currently developed HPLC method was developed, optimized and validated for the analysis of bromelain in pineapple water. It appeared that analysis were supported with C18 (150 $\mathrm{mm} \times 4,6 \mathrm{~mm})$ as stationary phase, methanol-air (70:30) as mobile phase with flow rate of $1.0 \mathrm{~mL} / \mathrm{min}$ and PDA as a detector at $230 \mathrm{~nm}$. This method is selective, accurate, precise, efficient and simple to determination bromelain level in pineapple water. It was shown to be applicable for the study of shelf life of pineapple water based on bromelain content. With a decrease of $91.17-99.14 \%$ from 1 to $8 \mathrm{~h}$ at $10^{\circ} \mathrm{C}$. Bromelain content in pineapple juice was not statistically significantly $(\alpha=0.05)$ after $8 \mathrm{~h}$ storage at $10^{\circ} \mathrm{C}$ at $2 \mathrm{~min}$.

\section{ACKNOWLEDGEMENT}

The authors are grateful for a research grant (SK No.3/E/KPT/2018) from the Ministry of Research, Technology and Higher Education of the Republic of Indonesia.

\section{REFERENCES}

1. Directorate general of horticulture ministry of agriculture republic of Indonesia. Postharvest guide of pineapple. Jakarta: Directorate of Cultivation and Postharvest Fruit. 2014

2. Poh SS, Abdul Majid FA. Thermal stability of free bromelain and bromelainpolyphenol complex in pineapple juice. Department of Bioprocess Engineering, Malaysia: Faculty of Chemical Engineering Universiti Teknologi Malaysia; 2011.

3. Pavan R, Jain S, Shraddha Kumar A. Properties and therapeutic application of bromelain: a review. Biotechnol Res Int. 2012;2012:976203.
4. Manzoor Z, Nawaz A, Mukhtar H, Haq I. Bromelain: Methods of extraction, purification and therapeutic applications. Braz Arch Biol Technol.

5. Baez R, Lopes MTP, Salas CS, Hernandez M. In vivo antitumoral activity of stem pineapple (Ananas comosus) bromelain. Planta Med. 2007;73:1377-83.

6. Almeida RAC, Sousa Lima FCM, Vasconcelos BCE. Is bromelain an effective drug for the control of pain and inflammation associated with impacted third molar surgery? Int J Oral Maxillofac Surg.

7. Akubor PI. Quality characteristics and storage properties of squash prepared from pineapple (Ananas comosus) fruit juice. Asian J Biotechnol Bioresour. 2017;1(4):1-8.

8. Laorko A, Tongchitpakdee S, Youravong W, Storage quality of pineapple juice non-thermally pasteurized and clarified by microfiltration. J Food Eng. 2013;116(2):554-61.

9. Kumaunang $M$, Kamu V. Activity of bromeline enzyme from pineapple skin extract (Ananas comosus). Manado: Universitas Sam Ratulangi; 2011.

10. Jaci VN, Diego M, Jaqueline S, Antônio CN, Ana L, Denise R, et al. Effect of salt stress on the activity of bromelain in pineapple plants grown In vitro. From 5th Congress of the Brazilian Biotechnology Society (SBBIOTEC) Florianópolis: 2013; Brazil.

11. Priya SP, Jayakumar, Mathai $\mathrm{V}$, Chintu, Babu S. Immobilization and Kinetic Studies of Bromelain: A Plant Cysteine Bromelin From Pineapple (Ananas comosus sp.) Plant Parts. Int J Med Health Sci. 2012:1(3):10-6.

12. Xue Y, Wu CY, Branford WCJ, Ning $X$, Nie HL, Zhu LM. Chemical modification of stem bromelain with anhydride groups to enhance its stability and catalytic activity. J Mol Catal B Enzym. 2010;63(3):188-193.

13. Costa HB, Fernandes PMB, Romao W, Ventura JA. A new procedure based on column chromatography to purify bromelain by ion exchange plus gel filtration chromatographies Industrial Crops and Products.

14. Sigma-Aldrich (https://www.sigmaaldrich.com). Darmstadt. Access on $27^{\text {th }}$ November 2018. HPLC Analysis of bromelain on TSKgel ${ }^{\circledR}$ BioAssist ${ }^{\circledR}$ S vs. competitive S column. 2018 Merck KGaA. https://www.sigmaaldrich.com/ technical-documents/articles/analytical-applications/hplc/hplc-analysis-ofbromelain-g1006655.html 
15. Wani SS, Mashru RC. Sensitive and selective methods for determination of proteolytic activity of formulation containing bromelain and trypsin as proteolytic enzymes. Int J Pharm Sci Res. 2014;5(11):4838-45.

16. Hasson KJ. Comparative study of prepared bromelain gel formulations and their evaluation by HPLC determination. Al-Mustansiriyah Journal for Pharmaceutical Sciences. 2016;16(2):77-81.
17. Majid FAA, Gani AM, Talib SZ, Hasyim KK. Stability of bromelain-polyphenol complex in pineapple juice. J Teknol. 49(F):27-38.

18. International Conference on Harmonization, Validation of analytical procedures: text and methodology Q2 (R1).

\section{GRAPHICAL ABSTRACT}

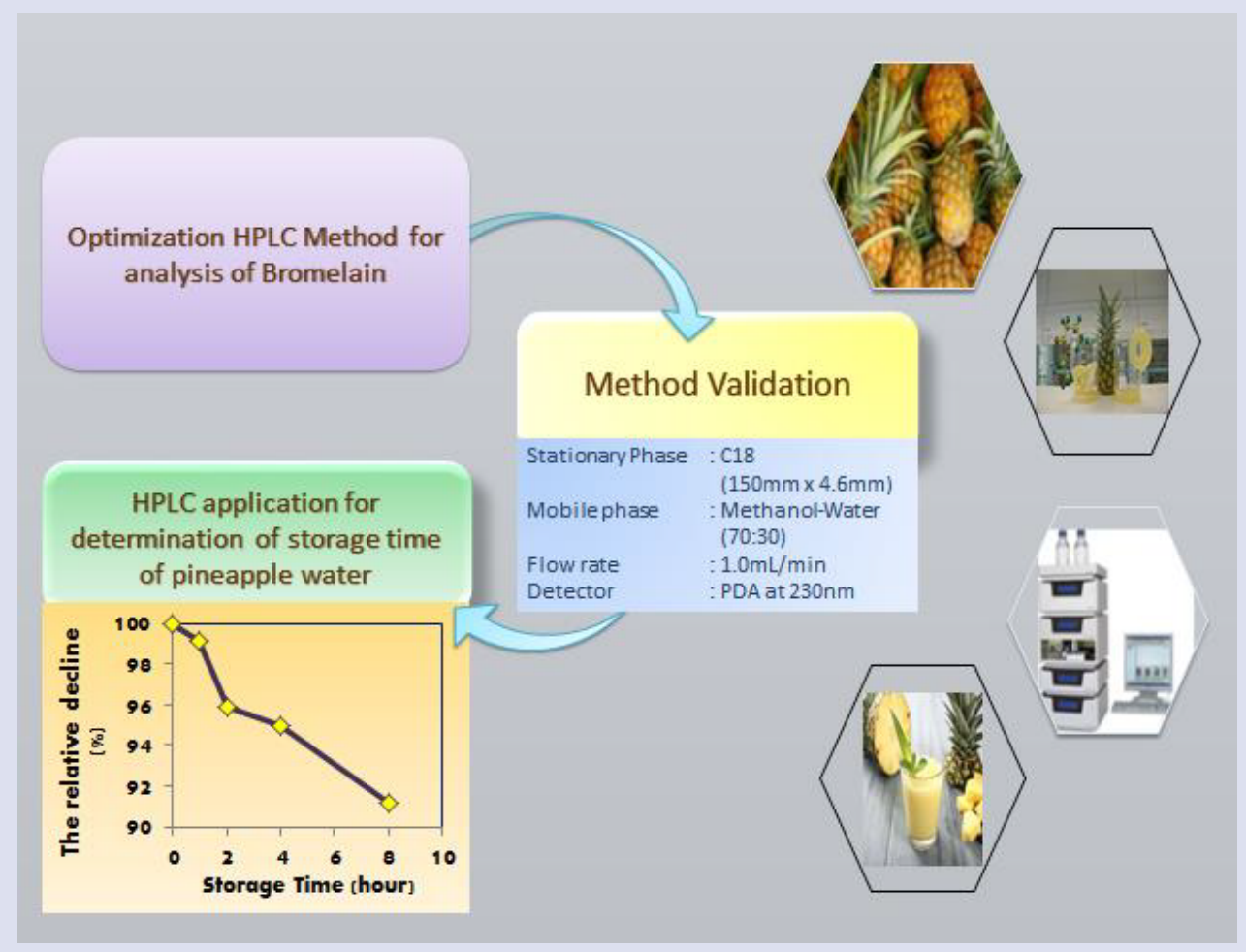

\section{ABOUT AUTHORS}

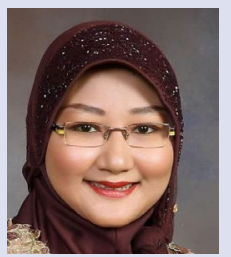

Novi Yantih: Novi Yantih is as an associate professor in Pharmacy Faculty of Universitas Pancasila, Indonesia. She has over 15 scientific papers. She is a recognized expert in areas of analytical chemistry and bioanalysis for pharmacokinetics study and drug discovery. She has graduated her PhD in Faculty of Pharmacy, Universitas Indonesia in January 2018. Recently, she investigated about N-acetyltransferase-2 genetic polymorphisms in Melanesian ethnicity and effect of pineapple as hepatoprotector on INH metabolism. Her contributions in this publication were responsible for optimization and validating of high performance liquid chromatography to determine bromelain for studying of storage time of pineapple water.

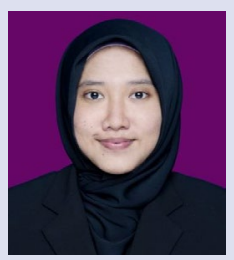

Alfadella Methananda: Alfadella Methananda was graduated from Faculty of Pharmacy, Universitas Pancasila, Indonesia in July 2016. Her contribution for this publication was helping optimization process and determining bromelain of sample by using high performance liquid chromatography.

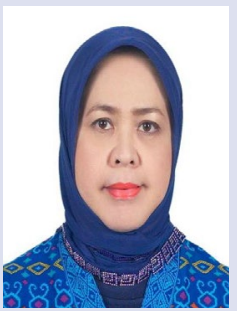

Yahdiana Harahap: Yahdiana Harahap has completed her PhD at the age of 39 from Department of Pharmacy, Institute Technology Bandung, Indonesia. Now she is the Head of Biavailability and Bioequivalence laboratory Faculty of Pharmacy, Universitas Indonesia. She has published 40 papers published in both International and National Journals. She has been invited to be the speakers in many international conference, especially in the field of Bioanalysis technique. She currently serves as an expert at Indonesia National Agency of Drug and Food Control. For this publication, she supervised the validation process of high performance liquid chromatography to determine bromelain in pineapple water. 


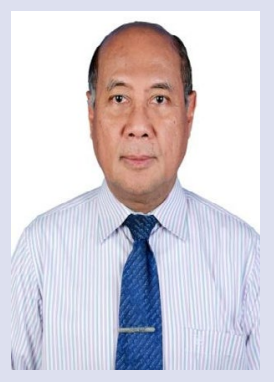

Wahono Sumaryono: Wahono Sumaryono has completed his Ph.D (Dr.rer.nat) in July 1990, from Institute for Pharmaceutical Biology - Technical University "Carolo - Wilhelmina", Braunschweig-Fed. Rep.of Germany- Now he is Professor in Natural Product Chemistry at Faculty of Pharmacy Universitas Pancasila Jakarta, since 2007. He served as Dean of the Faculty during Nov 2011 - March 2014, and as Rector of Universitas Pancasila since March 2014. He has published 10 International Scopus journals in the field of Natural Products and related subjects. His contribution for this publication was a supervisor of the extraction and characterization process of bromelain from pineapple.

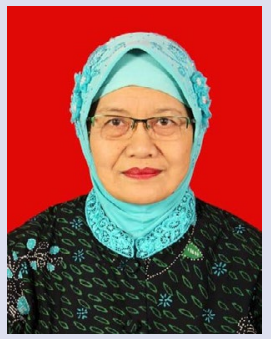

Lestari Rahayu: Lestari Rahayu was a student of Master Degree Program in Faculty of Pharmacy, Universitas Airlangga on 1985-1988. She is an associate professor in Universitas Pancasila. Her research is in the field of pharmacology studies of Natural Products and related subjects. She has published 7 papers in International and National Journals. She was also presented her research in congress/seminar/workshop as oral or poster presentation. She contributed for characterization process of bromelain from pineapple in this publication.

Cite this article:Yantih N, Methananda A, HarahapY, SumaryonoW, Rahayu L. Validation of High-Performance Liquid Chromatography for Determination of Bromelain in Pineapple (Ananas comosus (L) Merr) Water. Pharmacog J. 2019;11 (5):901-6. 